\title{
PENERAPAN SUPERVISI PENDIDIKAN DALAM MENINGKATKAN PROSES PEMBELAJARAN DI SEKOLAH
}

\author{
Nama: Rahma Nella \\ Email: rahmanella12@gmail.com
}

\begin{abstract}
ABSTRAK
Supervisi merupakan suatu aktifitas pembinaan yang direncanakan untuk membantu para guru dan pegawai sekolah dalam melakukan pekerjaan secara efektif agar dapat meningkatkan proses pembelajaran. Kegiatan supervisi pendidikan sangat diperlukan oleh guru, karena bagi guru yang bekerja setiap hari di sekolah, tidak ada pihak lain yang lebih dekat dan mengetahui dari dalam segala kegiatannya, kecuali Kepala Sekolah. Guru merupakan salah satu faktor penentu rendahnya mutu hasil pendidikan. Karena terdapat hubungan langsung antara kinerja guru dengan prestasi belajar siswa. Rendahnya mutu pendidikan di Indonesia menjadi penyebab utama rendahnya kualitas sumber daya manusia Indonesia. Oleh karena itu supervisi pendidikan sangat dibutuhkan untuk peningkatan mutu pendidikan.
\end{abstract}

Kata Kunci: supervisi, mutu guru, mutu pendidikan

\section{LATAR BELAKANG}

Kondisi pendidikan di Indonesia sampai sekarang ini masih rendah dikarenakan rendahnya kualitas sumber daya manusia di Indonesia. Rendahnya kualitas sumber daya manusia ini disebabkan oleh mutu pendidikan di Indonesia yang masih rendah. Pendidikan merupakan suatu kegiatan interaksi antara peserta didik dengan para pendidik serta berbagai sumber pendidikan yang berlangsung dalam situasi pendidikan, pengajaran, latihan serta bimbingan. Agar pencapaian hasil pembelajaran maksimal, maka dibutuhkan sosok guru yang professional. Hal itu dikarenakan dalam dunia pendidikan khususnya bagian pengajaran, tolak ukur keberhasilannya adalah guru. Guru memiliki potensi untuk berkreasi dan meningkatkan kinerjanya. Namun,sering kali banyak faktor yang menghambat guru-guru dalam mengembangtkan berbagai potensinya secara optimal, baik berupa kemampuan guru itu sendiri dalam mengajar maupun sarana dan prasarana pendidikan yang tersedia. Oleh karena itu, supervisi pendidikan sangat diperlukan bagi para guru agar pekerjaan yang dilakukan oleh guru bisa berjalan sesuai dengan ketentuan.

Berdasarkan uraian diatas, permasalahan dalam tulisan ini adalah (1) Bagaimana Pelaksanaan supervisi pendidikan oleh Kepala Sekolah sebagai Supervisor?(2)Bagaimana implementasi/penerapan supervisi pendidikan dalam meningkatkan proses pembelajaran di sekolah? Tujuan tulisan ini adalah untuk mengetahui bagaimana implementasi/penerapan supervisi pendidikan dalam meningkatkan proses pembelajaran di sekolah.

\section{PEMBAHASAN}

Supervisi dalam kaitannya dengan pendidikan menurut (Suryani, 2016) adalah pembinaanguru.Hal tersebut dikarenakan guru merupakan salah satu faktor penentu rendahnya mutu hasil pendidikan.Supervisi tidak hanya untuk memperbaiki mutu mengajar guru, tapi juga membina pertumbuhan profesi guru dalam arti luas, termasuk di dalamnya pengadaan fasilitas-fasilitas, pelayanan 
kepemimpinan dan pembinaan hubungan yang baik kepada semua pihak yang terkait.Oleh karena itu, supervisi pendidikan sangat diperlukan bagi para guru agar pekerjaan yang dilakukan oleh guru bisa berjalan sesuai dengan ketentuan. Menurut (Sabandi, 2013) supervisi seharusnya dilakukan untuk menjamin pembelajaran yang berkualitas, karena terdapat hubungan langsung antara kinerja guru dengan prestasi belajar siswa. Dalam artian, semakin tinggi kinerja guru maka semakin tinggiprestasi belajar siswa,

Pelaksanaan supervisi pendidikan oleh kepala sekolah sebagaimana menurut (Suryani, 2016), maka harus mempumelakukan berbagai pengawasan dan pengendalian untuk meningkatkan proses belajar mengajar. Pengawasan dan pengendalian merupakan kontrol agar kegiatan pendidikan di sekolah terarah sesuai tujuan yang telah ditetapkan. Pengawasan dan pengendalian juga merupakan tindakan pencegahan (preventive) agar para guru tidak melakukan penyimpangan dan lebih berhati-hati dalam melaksanakan tugasnya.

Perkembangan supervisi pendidikan menurut (Sabandi, 2013) berkembang seiring dengan perkembangan ilmu pengetahuan, teknologi, serta sosial ekonomi dan budaya masyarakat. Ada beberapa pendekatan-pendekatan supervisi yang lebih popular untuk meningkatkan profesional guru yaitu dapat dilakukan dengan menggunakan pendekatan supervisi klinis, pengembangan, dan diferensial. Masing pendekatan tersebut memiliki kekuatan dan kelemahan. Model asli supervisi klinis terdiri dari delapan langkah, yaitu: membangun hubungan guru-supervisor, perencanaan dengan guru (pelajaran, hasil yang diharapkan, masalah pembelajaran, bahan dan metode, proses pembelajaran, pemberian umpan balik dan evaluasi), merencanakan strategi untuk observasi, mengamati pembelajaran, menganalisis proses belajar mengajar, perencanaan strategi konferensi supervisor-guru, melakukan konferensi guru, dan pemberbaharui perencanaan pelajaran atau unit berikutnya. Sedangkan pada Model supervisi pengembangan didasarkan pada asumsi bahwa guru memiliki beragam pengalaman, kemampuan, dan tingkat pengembangan karir yang berbeda.dan pada supervisi diferensial, pendekatan supervisi yang menyediakan pilihan jenis supervisi dan evaluasi yang sesuai dengan kebutuhan guru. Supervisi diferensial dengan mempertimbangkan perbedaan individual antara guru dan hubungan manusia antara supervisor dan guru.s

Implementasi supervisi disekolah sebagaimana menurut (Lazwardi, 2016) masih sering menemui kendala diantaranya pengadaan calon supervisor yang kurang tepat. Cara terbaik dalam pengadaan calon kepala sekolah atau supervisor pada orang-orang yang sudah berpengalaman menjadi guru dan memiliki keahlian sebagai sebagai kepala sekolah atau supervisor. Supervisi memerlukan kerativitas tinggi dari pada supervisor untuk mencari solusi dari problem yang ada di lapangan. Belum banyak supervisor yang memiliki kreativitas tinggi dalam memecahkan masalah. Disinilah pentingnya supervisor meningkatkan kompetensi secara maksimal, sehingga ia mampu mengembangkan gaya berpikir yang kreatif, kritis, inovatif dan produktif. Rendahnya kualitas lembaga pendidikan akan berdampak pada kualitas guru dan kualitas guru yang berada dibawah standar akan membawa pengaruh besar pada peserta dedik. Supervisor yang berkualitas adalah supervisor yang dapat memberikan bantuan kepada guru ke arah usaha pemecahan masalah dan perbaikan kualitas proses pembelajaran secara sistematis, berkelanjutan dan komprehensif.

\section{KESIMPULAN DAN SARAN}

Dari hasil pembahasan di atas dapat disimpulkan bahwa supervisi pendidikan di sekolah-sekolah masih belum terjalan dengan baik. Hal tersebut dikarenakan beberapa kendala seperti pengadaan calon supervisor yang kurang tepat sehingga mutu pendidikan di sekolah-sekolah masih rendah. Sebaiknya supervisi pendidikan harus dilaksanakan sebagaimana mestinya sehingga dapat meningkatkan proses

pembelajaran di sekolah. Karena supervisi seharusnya dilakukan untuk menjamin pembelajaran yang berkualitas. 


\section{REFERENSI}

Lazwardi, D. (2016). IMPLEMENTASI SUPERVISI PENDIDIKAN DI SEKOLAH/MADRASAH. Jurnal Kependidikan Islam, 6(1), 22. https://doi.org/https://doi.org/10.24042/alidarah.v6i1.794

Sabandi, A. (2013). Supervisi Pendidikan Untuk Pengembangan Profesionalitas Guru Berkelanjutan. Pedagogi, Jurnal Ilmiah Ilmu Pendidikan, XIII(2), 1-9. Retrieved from http://ejournal.unp.ac.id/index.php/pedagogi/article/view/4275

Suryani, C. (2016). Implementasi Supervisi Pendidikan Dalam Meningkatkan Proses Pembelajaran Di Min Sukadamai Kota Banda Aceh. Jurnal Ilmiah Didaktika, 16(1), 23. https://doi.org/10.22373/jid.v16i1.585 